\author{
Original Article
}

\title{
Distribution pattern of arthropods on the leaf surfaces of Acacia auriculiformis saplings
}

\author{
Padrão de distribuição de artrópodes nas superfícies foliares de plantas de Acacia \\ auriculiformis
}

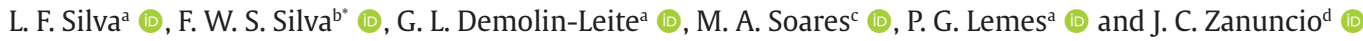 \\ aUniversidade Federal de Minas Gerais - UFMG, Instituto de Ciências Agrárias, Montes Claros, MG, Brasil \\ bUniversidade Federal do Acre - UFAC, Centro de Ciências Biológicas e da Natureza, Rio Branco, AC, Brasil \\ 'Universidade Federal dos Vales do Jequitinhonha e Mucuri - UFVJM, Departamento de Agronomia, Diamantina, MG, Brasil \\ dUniversidade Federal de Viçosa - UFV, Departamento de Entomologia/BIOAGRO, Viçosa, MG, Brasil
}

\begin{abstract}
Acacia auriculiformis A. Cunn. Ex Benth. (Fabaceae), a non-native pioneer species in Brazil with fast growth and rusticity, is used in restoration programs. Our goal was to assess during a 24-month survey the pattern of arthropods (phytophagous insects, bees, spiders, and predator insects) on the leaf surfaces of A. auriculiformis saplings. Fourteen species of phytophagous, two of bees and eleven of predators were most abundant on the adaxial surface. The values of the ecological indexes (abundance, diversity, and species richness) and the rarefaction, and k-dominance curves of phytophagous, bees and arthropod predators were highest on the adaxial leaf surface of A. auriculiformis. The k-dominance and abundance of Aleyrodidae (Hemiptera) (both leaf surfaces), the native stingless bee Tetragonisca angustula Latreille (Hymenoptera: Apidae) (both leaf surfaces) and the ant Brachymyrmex sp. (adaxial surface) and Pheidole sp. (Hymenoptera: Formicidae) (abaxial surface) were the highest between the taxonomic groups of phytophagous, bees, and predators, respectively on A. auriculiformis saplings. The ecological indexes and rarefaction, abundance, and k-dominance curves of phytophagous insects, bees, and predators were highest on the adaxial leaf surface. The preference of phytophagous insects for the adaxial leaf surface is probably due to the lower effort required to move on this surface. Understanding the arthropod preferences between leaf surfaces may help to develop sampling and pest management plans for the most abundant phytophagous insects on A. auriculiformis saplings. Also, knowledge on the preference pattern of bees and predators may be used to favour their conservation.
\end{abstract}

Keywords: insect sampling, insect conservation, leaf surfaces, pest management, preference pattern.

\begin{abstract}
Resumo
Acacia auriculiformis A. Cunn. Ex Benth. (Fabaceae), espécie pioneira com rápido crescimento e rusticidade, é utilizada em programas de recuperação de áreas degradadas. 0 objetivo deste trabalho foi avaliar, durante 24 meses, o padrão de distribuição de artrópodes (insetos fitófagos, abelhas, aranhas e insetos predadores) nas superfícies foliares de A. auriculiformis. Quatorze espécies de fitófagos, duas de abelhas e onze de predadores foram mais abundantes na superfície adaxial. Índices ecológicos (abundância, diversidade e riqueza de espécies) e curvas de rarefação e dominância-k de fitófagos, abelhas e artrópodes predadores foram maiores na face adaxial de folhas de A. auriculiformis. A dominância-k e a abundância de Aleyrodidae (Hemiptera) (ambas as superfícies foliares), da abelha nativa sem ferrão Tetragonisca angustula Latreille (Hymenoptera: Apidae) (ambas as superfícies foliares) e das formigas Brachymyrmex sp. (superfície adaxial) e Pheidole sp. (Hymenoptera: Formicidae) (superfície abaxial) foram as maiores entre os grupos taxonômicos de fitófagos polinizadores e predadores, respectivamente, em plantas jovens de A. auriculiformis. A abundância, diversidade e riqueza e as curvas de rarefação e dominância-k de artrópodes fitófagos, abelhas e predadores foram maiores nas superfícies adaxiais das folhas dessa árvore. A preferência pela superfície adaxial da folha se deve, provavelmente, ao menor esforço para se movimentarem na mesma. Compreender as preferências dos artrópodes pelas superfícies foliares pode auxiliar no desenvolvimento de planos de amostragem e manejo de pragas em A. auriculiformis. Além disso, o conhecimento da distribuição de abelhas e predadores pode favorecer a conservação desses insetos.
\end{abstract}

Palavras-chave: amostragem de insetos, conservação de insetos, superfície foliar, manejo de pragas, padrão de preferência.

*e-mail: farleyw@gmail.com

Received: September 16, 2020 - Accepted: April 21, 2021 


\section{Introduction}

Insects use plant leaves for food, oviposition, and refuge, and the leaf characteristics can determine the interaction between plants and insects. Phytophagous (e.g., sap-sucking) insects, usually, prefer the abaxial leaf surface due to its softer tissue, thinner epidermis, and more prominent ribs (Leite et al., 2008; Fiene et al., 2013; Damascena et al., 2017). In addition, insects on this leaf surface are more protected against predators and climatic factors (e.g., solar radiation) (Leite et al., 2011). However, plants are not passive with mechanical defenses (e.g., trichomes) and secondary metabolites to protect themselves from herbivores (Lima et al., 2017). The preference for specific leaf surfaces on their host plants may help to develop sampling and pest management plans for phytophagous insects and to conserve bees and predator populations (Naranjo and Flint, 1995; Leite et al., 2008).

The Acacia auriculiformis A. Cunn. ex Benth. (Fabaceae) is a non-native pioneer species used as a model to study leaf surface preference patterns by arthropods. Acacia spp. (Fabaceae) are used to recover degraded areas (Balieiro et al., 2017), although the introduction of non-native plants may impact natural ecosystems. The abiotic characteristics of the area and the life-history facilitate the establishment and dispersal of $A$. mangium in the Amazonian savannas (Aguiar Junior et al., 2014). On the other hand, the local biotic resistance may reduce the dispersal of introduced Acacia spp. as an invasive species (Londe et al., 2020). The durability of the A. auriculiformis wood is longer and the susceptibility to diseases and adaptability to poor soils by this plant is high (Diouf et al., 2006; Wong et al., 2011; Rahman et al., 2017). Acacia auriculiformis can increase moisture retention, deposition of potassium and organic carbon in the soil (litter) and also the phyto-extraction of heavy metals from the soil (through mycorrhizal associations) (Rana and Maiti, 2018) in addition to biological fixation of atmospheric nitrogen via bacteria in its roots. Arthropods on this and other Acacia spp. (Van Der Colff et al., 2015; Maoela et al., 2016; Hager and Krausa, 2019; Rodríguez et al., 2020) have been studied, but their preference pattern for the leaf surface of this plant remains unknown.

Our goal was to assess, during 24-month, the preference and ecological indexes (abundance, diversity, and species richness) of arthropods on leaf surfaces of $A$. auriculiformis saplings (young trees) used to recover a disturbed area. Knowing the spatial preference and ecological indexes of phytophagous insects is essential for sampling plans to manage these insects and to conserve beneficial arthropods. The hypothesis tested was that phytophagous insects would prefer the abaxial leaf surface and, thus, resulting in higher ecological indexes on this surface where leaf tissues and structures facilitate their feeding.

\section{Material and Methods}

\subsection{Acacia auriculiformis}

Acacia auriculiformis is native from Australia, Papua New Guinea, and Indonesia (Turnbull 1986). Its leaves are dense, bipinnate with petioles and size from 8 to $22.5 \mathrm{~cm}$ and 10 to $52 \mathrm{~mm}$ with three longitudinal and many secondary ribs (Doran and Turnbull, 1997). This plant is a priority species for the International Union of Forestry Research Organisations (IUFRO) for research and development in tropical areas (Wickneswari and Norwati, 1993). Its wood is of high quality for particle board, pulpwood, tannin and timber (Firmansyah et al., 2020).

\subsection{Arthropods survey and identification}

Few arthropod specimens (up to 3 individuals), per species, were collected using an aspirator, stored in flasks with $70 \%$ alcohol, separated into morphospecies, and sent to specialists for identification (see acknowledgments). The numbers of arthropods were visually counted every two weeks on the abaxial and adaxial leaf surfaces between 7:00 and 11:00 A.M. in the apical, middle, and basal parts of the canopy in the north, south, east and west orientations during sunny days with low wind speed and without rain on A. auriculiformis. The total sample effort was 27,648 leaves from 48 A. auriculiformis saplings (at six-months old after planting). This evaluation was at random on both leaf surfaces (12 leaves/plant/survey), during 24 months, on the entire plant (vertical and horizontal axes), capturing as many insect and spider species as possible, especially the rarest ones. The mean data per leaf per sapling, combining the data of height and cardinal sampling, was used to analyse the abundance, diversity, and species richness on $A$. auriculiformis saplings.

\subsection{Experimental site}

The work was carried out during 24 months (from April 2015 to March 2017) in a severely disturbed area of the "Instituto de Ciências Agrárias da Universidade Federal de Minas Gerais" (ICA/UFMG), Montes Claros municipality, Minas Gerais State, Brazil (latitude 1651'38” S, longitude 445'00" W, altitude $943 \mathrm{~m}$ ), with Terminalia argentea Mart. \& Zucc (Combretaceae), Platycyamus regnellii Benth (Fabaceae), and Sapindus saponaria L. (Sapindales: Sapindaceae). The climate of this area is tropical with a dry winter, annual precipitation between 1000 and $1300 \mathrm{~mm}$ and average annual temperature $\geq 18^{\circ} \mathrm{C}$, according to the Köppen classification (Alvares et al., 2013). The soil is Neosol Litolic, with an Alic horizon, and its physical-chemical characteristics have been described (Silva et al., 2020).

\subsection{Experimental design}

Acacia auriculiformis seedlings were prepared in plastic bags ( $16 \times 24 \mathrm{~cm}$ ) in a nursery in March 2014 with a mixture of $160 \mathrm{~g}$ of reactive natural phosphate. The seedlings (30 cm tall) were planted in holes ( $40 \times 40 \times 40 \mathrm{~cm}$ ) at two meters apart. The soil in the holes was corrected with dolomitic limestone to increase the base saturation to $50 \%$ and natural phosphate, gypsum, fried trace elements, potassium chloride, and micronutrients equivalent according to the soil analysis were added. A total of $20 \mathrm{~L}$ of dehydrated sewage sludge, which chemical and biological characteristics have been described (Silva et al., 2020) was placed in a single-dose per hole. Forty-eight A. auriculiformis seedlings were watered twice a week until the beginning 
of the rainy season (i.e., October). The experimental design was completely randomized and insects evaluated on the leaf surfaces were the treatments.

\subsection{Statistical analysis}

The abundance and species richness of arthropods were the total number of individuals and species, respectively, per leaf surface per sapling as the sampling unit (Begon et al., 2007). Diversity was calculated using the Hill's formula ( $1^{\text {st }}$ order $): \mathrm{N} 1=\exp \left(\mathrm{H}^{\prime}\right)$, where $\mathrm{H}^{\prime}$ is the Shannon Weaver diversity index, estimating the diversity with the current species number (Hill, 1973) using the BioDiversity Professional, Version 2 (Krebs, 1989). The k-dominance was calculated by plotting the percentage cumulative abundance against log species rank (Lambshead et al., 1983). This index values indicate the dominance and evenness distribution of individuals between species (Gee et al., 1985). Abundance and species rarefaction curves were made using the mentioned statistical program. The rarefaction is a measure of diversity comparing the variation in species richness with the number of individuals collected. Data of abundance, diversity, and species richness of phytophagous, bees and predator arthropods, and their individual number were submitted to the non-parametric statistical hypothesis, Wilcoxon signed-rank test $(P<0.05)$ (Wilcoxon, 1945), using SAEG, version 9.1 (Saeg, 2007) (Supplier: "Universidade Federal de Viçosa"). The data presented were those significant $(P<0.05)$ and the remaining ones, used to calculate the ecological indexes, are in the supplementary material I.

\section{Results}

Fourteen species of phytophagous, two of bees and eleven of predators were most abundant $(P<0.05)$ on the adaxial and one of phytophagous and one of predator on the abaxial surface of A. auriculiformis. The values of ecological indexes (abundance, diversity, and species richness) and the rarefaction, abundance, and k-dominance curves of phytophagous, bees and arthropod predator were highest on the adaxial leaf surface $(P<0.05)$ of this plant (Table 1 , Figures 1-3). The rarefaction curves of predators and bees reached the asymptote on the adaxial surface and that of phytophagous almost reached a similar shape (Figure 1).

The $k$-dominance $(\mathrm{k}$ ) and abundance $(\mathrm{n})$ of Aleyrodidae (Hemiptera) (adaxial: $\mathrm{k}=23.0, \mathrm{n}=88$; abaxial: $\mathrm{k}=47.4$, $\mathrm{n}=36$ ), of the native stingless bee Tetragonisca angustula Latreille (Hymenoptera: Apidae) (adaxial: $\mathrm{k}=72.6, \mathrm{n}=37$, abaxial: $\mathrm{k}=100.0, \mathrm{n}=1)$ and that of the ant Brachymyrmex sp. (adaxial: $k=30.7, n=212$ ) and Pheidole sp. (Hymenoptera: Formicidae) (abaxial: $\mathrm{k}=29.8, \mathrm{n}=17$ ) were the highest between the taxonomic groups of phytophagous, pollinators and predator, respectively, on $A$. auriculiformis saplings (Figures 2, 3).

\section{Discussion}

The highest numbers of phytophagous insects (e.g., $P$. torridus), bees (e.g., A. mellifera) and predators (e.g., Polybia sp.) increasing the species richness and of rarefaction curves with a greatest diversity of species of these groups on the adaxial leaf surface of A. auriculiformis saplings, may be due to lower effort by them on this surface (e.g., walk) (Le Goff et al., 2009). These results did not confirm our hypothesis: phytophagous insects would prefer the abaxial leaf surface with highest ecological indexes on this surface due to feeding facility (e.g., softer tissue) and high protection (e.g., predators) (Leite et al., 2008, 2011; Fiene et al., 2013; Damascena et al., 2017). Acacia auriculiformis leaves are dense, bipinate with petioles and 8 to $22.5 \mathrm{~cm}$ long and 10 to $52 \mathrm{~mm}$ wide, with three longitudinal and many secondary ribs (Doran and Turnbull, 1997). Leaf characteristics, including regular shape or not, hairiness, roughness, wax content, and type and number of veins, can favour insect and the preference for the leaf surface (adaxial or abaxial) requiring lower effort for the movement (Peeters, 2002; Gorb et al., 2008; Gorb and Gorb, 2009; Prüm et al., 2012; Salerno et al., 2018).The normalized safety factor of the traction force of Nezara viridula (L.) (Hemiptera: Pentatomidae) varied with the leaf surface and plant species (Salerno et al., 2018). This factor on the adaxial leaf surface of Solanum melongena $\mathrm{L}$.
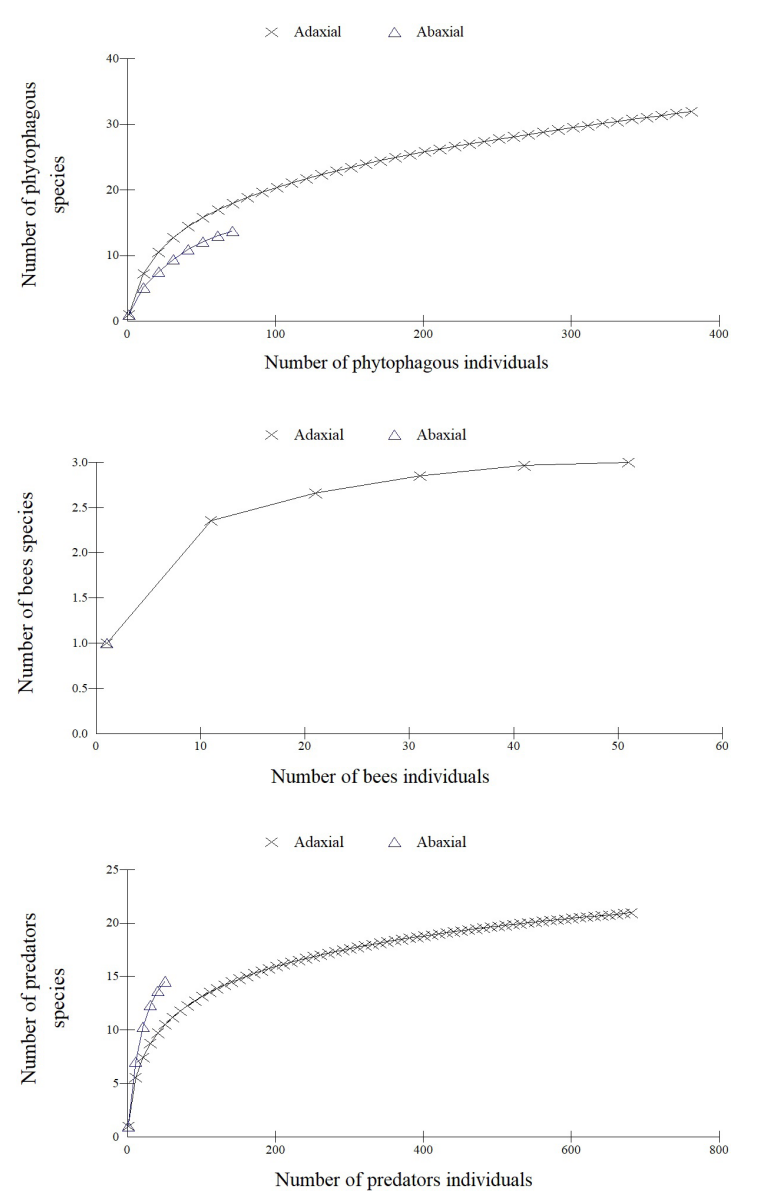

Figure 1. Rarefaction curves of phytophagous, bees and predators on the abaxial and adaxial leaf surfaces of Acacia auriculiformis (Fabaceae). 
Table 1. Number of arthropods and of their ecological indexes (mean \pm SE) on the abaxial and adaxial leaf surfaces of Acacia auriculiformis (Fabaceae).

\begin{tabular}{|c|c|c|c|c|}
\hline \multirow{2}{*}{ Arthropods } & \multicolumn{2}{|c|}{ Leaf surface } & \multicolumn{2}{|c|}{$\mathbf{T W}^{*}$} \\
\hline & Abaxial & Adaxial & VTE & $\boldsymbol{P}$ \\
\hline Araneae: Araneidae & $0.13 \pm 0.05$ & $0.81 \pm 0.07$ & 2.06 & 0.02 \\
\hline Oxyopidae & $0.00 \pm 0.00$ & $0.17 \pm 0.06$ & 2.52 & 0.01 \\
\hline Sparassidae, Quemedice sp. & $0.06 \pm 0.03$ & $0.00 \pm 0.00$ & 1.75 & 0.04 \\
\hline Coleoptera: Chrysomelidae, Cerotoma sp. & $0.00 \pm 0.00$ & $0.17 \pm 0.06$ & 2.52 & 0.01 \\
\hline Diabrotica speciosa Germar & $0.00 \pm 0.00$ & $0.19 \pm 0.06$ & 2.94 & 0.00 \\
\hline Stereoma anchoralis Lacord. & $0.08 \pm 0.04$ & $0.94 \pm 0.19$ & 4.43 & 0.00 \\
\hline Coccinellidae, Cycloneda sanguinea L. & $0.00 \pm 0.00$ & $0.08 \pm 0.04$ & 2.03 & 0.02 \\
\hline Curculionidae, Lordops sp. & $0.06 \pm 0.03$ & $0.00 \pm 0.00$ & 1.75 & 0.04 \\
\hline Naupactus sp. & $0.00 \pm 0.00$ & $0.06 \pm 0.03$ & 1.75 & 0.04 \\
\hline Diptera: Dolichopodidae & $0.08 \pm 0.04$ & $0.81 \pm 0.44$ & 4.76 & 0.00 \\
\hline Otittidae, Euxesta sp. & $0.00 \pm 0.00$ & $0.08 \pm 0.05$ & 1.75 & 0.04 \\
\hline Syrphidae, Syrphus sp. & $0.00 \pm 0.00$ & $0.15 \pm 0.05$ & 2.52 & 0.01 \\
\hline Hemiptera: Cicadellidae, Balclutha Hebe Kirkaldy & $0.04 \pm 0.02$ & $0.35 \pm 0.13$ & 2.28 & 0.01 \\
\hline Erythrogonia sexguttata Fabricius & $0.00 \pm 0.00$ & $0.08 \pm 0.05$ & 1.75 & 0.04 \\
\hline Unknown Membracidae species & $0.00 \pm 0.00$ & $0.77 \pm 0.22$ & 4.82 & 0.00 \\
\hline Membracis sp. & $0.00 \pm 0.00$ & $0.08 \pm 0.04$ & 2.03 & 0.02 \\
\hline Unknown Pentatomidae species & $0.04 \pm 0.02$ & $0.46 \pm 0.09$ & 4.02 & 0.00 \\
\hline Scutelleridae, Pachycoris torridus Scopoli & $0.04 \pm 0.04$ & $0.19 \pm 0.07$ & 1.93 & 0.03 \\
\hline Hymenoptera: Apidae, Apis mellifera L. & $0.00 \pm 0.00$ & $0.25 \pm 0.09$ & 2.94 & 0.00 \\
\hline Tetragonisca angustula Latreille & $0.02 \pm 0.02$ & $0.77 \pm 0.19$ & 4.67 & 0.00 \\
\hline Formicidae, Brachymyrmex sp. & $0.08 \pm 0.04$ & $4.42 \pm 1.51$ & 4.53 & 0.00 \\
\hline Camponotus sp. & $0.13 \pm 0.05$ & $3.06 \pm 0.44$ & 6.94 & 0.00 \\
\hline Cephalotes sp. & $0.00 \pm 0.00$ & $0.19 \pm 0.13$ & 1.75 & 0.04 \\
\hline Ectatomma sp. & $0.02 \pm 0.02$ & $0.63 \pm 0.17$ & 3.84 & 0.00 \\
\hline Pheidole sp. & $0.35 \pm 0.12$ & $2.50 \pm 0.37$ & 6.02 & 0.00 \\
\hline Pseudomyrmex termitarius Smith & $0.02 \pm 0.02$ & $1.08 \pm 0.21$ & 5.46 & 0.00 \\
\hline Vespidae, Polybia sp. & $0.00 \pm 0.00$ & $0.50 \pm 0.11$ & 4.67 & 0.00 \\
\hline Unknown Lepidoptera species & $0.02 \pm 0.02$ & $0.13 \pm 0.04$ & 1.95 & 0.03 \\
\hline Orthoptera: Proscopiidae,Cephalocoema sp. & $0.00 \pm 0.00$ & $0.19 \pm 0.13$ & 1.75 & 0.04 \\
\hline Romaleidae, Tropidacris collaris Stoll. & $0.02 \pm 0.02$ & $0.81 \pm 0.13$ & 5.46 & 0.00 \\
\hline Tettigoniidae & $0.00 \pm 0.00$ & $0.67 \pm 0.60$ & 5.74 & 0.00 \\
\hline \multicolumn{5}{|l|}{ Ecological indexes } \\
\hline Abundance of phytophagous & $1.58 \pm 0.47$ & $7.98 \pm 1.16$ & 6.38 & 0.00 \\
\hline Diversity of phytophagous & $1.11 \pm 0.21$ & $6.04 \pm 1.10$ & 2.18 & 0.01 \\
\hline Species richness of phytophagous & $0.67 \pm 0.10$ & $4.13 \pm 0.31$ & 7.28 & 0.00 \\
\hline Abundance of bees & $0.02 \pm 0.02$ & $1.06 \pm 0.23$ & 5.46 & 0.00 \\
\hline Diversity of bees & $0.00 \pm 0.00$ & $0.00 \pm 0.00$ & --- & --- \\
\hline Species richness of bees & $0.00 \pm 0.00$ & $0.63 \pm 0.09$ & 5.74 & 0.00 \\
\hline Abundance of predators & $1.19 \pm 0.17$ & $14.38 \pm 1.82$ & 7.43 & 0.00 \\
\hline Diversity of predators & $1.60 \pm 0.24$ & $6.51 \pm 0.96$ & 2.79 & 0.00 \\
\hline Species richness of predators & $1.20 \pm 0.31$ & $4.92 \pm 0.29$ & 7.18 & 0.00 \\
\hline
\end{tabular}

$\mathrm{N}=48$ per treatment. --- non generated. ${ }^{*} \mathrm{TW}=$ Test of Wilcoxon. ${ }^{\mathrm{E}} \mathrm{VT}=$ value of test. 

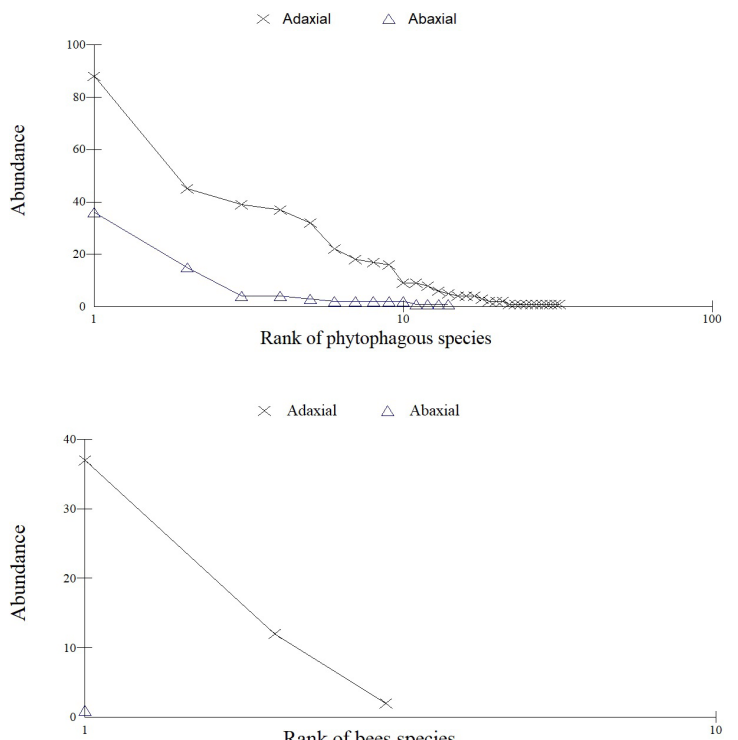

Rank of bees species

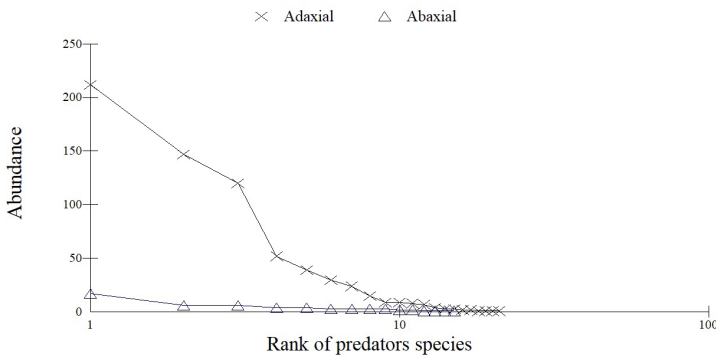

Figure 2. Abundance curves for phytophagous, bees and predators on the abaxial and adaxial leaf surfaces of Acacia auriculiformis (Fabaceae).

(Solanaceae), and Glycine max (L.) Merrill (Fabaceae) was higher followed by that on Cucurbita pepo L. (Cucurbitaceae) (Salerno et al., 2018).

The highest values of ecological indexes (abundance, diversity and species richness) and of abundance and k-dominance curves and of their asymptote rarefaction curves per functional groups of arthropods on the adaxial leaf surface of $A$. auriculiformis saplings may be due to leaf characteristics of this plant. The expected number of species, based on rarefaction curves, indicates that the diversity of arthropods differed between the leaf surfaces of $A$. auriculiformis. The asymptote of rarefaction curves on the adaxial surface indicates that the maximum number of species expected on this surface has been reached (Rice and Kelting, 1955).

The highest numbers and k-dominance on A. auriculiformis leaves of Aleyrodidae, such as Bemisia tabaci (Genn.), pest of several plants including Capsicum annum L. (Solanaceae), Cucumis melo L. (Cucurbitaceae), G. max and Phaseolus vulgaris L. (Fabaceae), and Solanum lycopersicon Mill. (Solanaceae) by sucking sap, injecting toxins, transmitting viruses and favours the development of fumagine (Zhang et al., 2004; Mansaray and Sundufu, 2009; Kim et al., 2017; Felicio et al., 2019; Oliveira et al.,

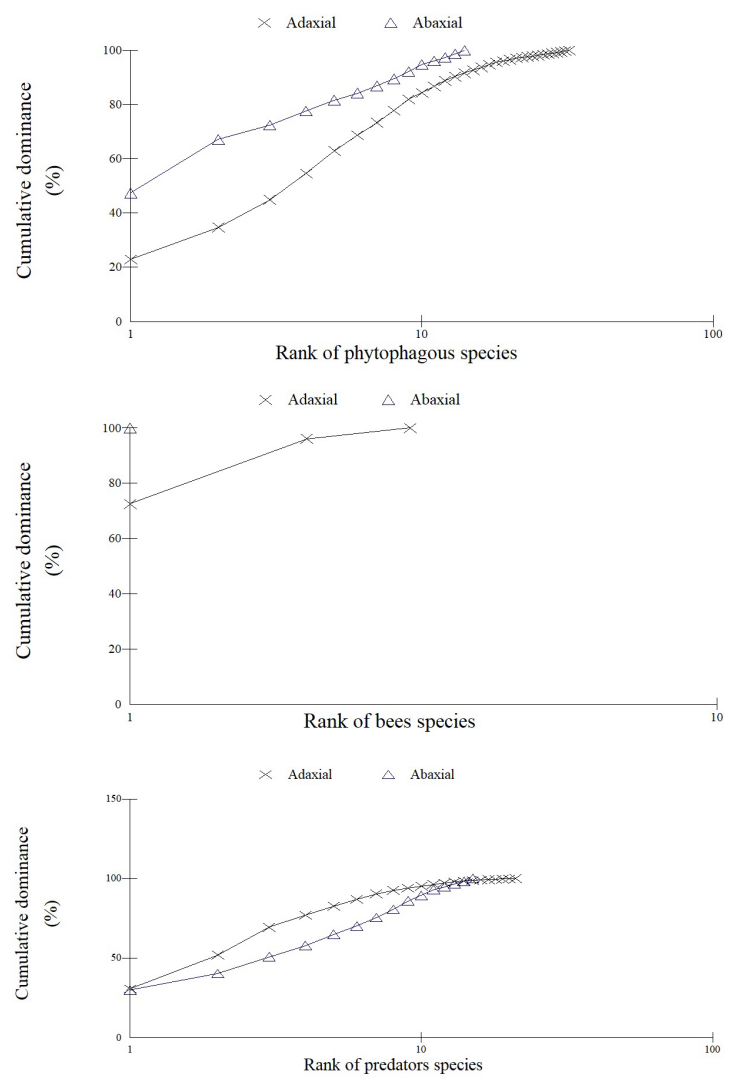

Figure 3. k-dominance curves for phytophagous, bees and predators on the abaxial and adaxial leaf surfaces of Acacia auriculiformis (Fabaceae).

2021). The predator Brachymyrmex sp., as one of the most abundant and with high k-dominance on A. auriculiformis leaves may be due to its protocooperating behaviour with sap-sucking hemipterans (e.g., Aleyrodidae) (Novgorodova, 2015; Sanchez et al., 2020) and the bee T. angustula (Giannini et al., 2012); and/or by feeding on extrafloral nectaries in the leaf petioles of this plant (Ghosh, 2015) as reported on Acacia mangium Willd. (Fabaceae) and Leucaena leucocephala (Lam.) (Fabaceae) trees (Hegde et al., 2013; Damascena et al., 2017). The numbers of individuals of $T$. angustula, an important pollinator, were the highest within the bees on A. auriculiformis plants (Grüter et al., 2011; Giannini et al., 2012). The high numbers of Brachymyrmex sp. can be a problem because this ant protects the potential pest Aleyrodidae against natural enemies. Dominant ants form mutualistic relationships with sap-sucking insects, increasing pest problems in agricultural systems (Sagata and Gibb, 2016).

\section{Conclusions}

The greatest numbers of individuals and peaks of the $\mathrm{k}$-dominance and the asymptote rarefaction curves of arthropods on the adaxial leaf surface of A. auriculiformis 
saplings is, probably, due to the lower effort for these organisms to move on this surface. The preferences of arthropods by leaf surfaces may help to develop sampling and pest management plans for the most abundant phytophagous insects (such as Hemiptera: Aleyrodidae) on $A$. auriculiformis saplings and to help maintain bee and predator populations for management purposes.

\section{Acknowledgements}

We would like to thank the anonymous reviewers; the Dr. Antônio Domingos Brescovit (Instituto Butantan, São Paulo, Brasil - Aracnidae), Dr. Ayr de Moura Bello (Fundação Oswaldo Cruz, Rio de Janeiro, Brasil - Coleoptera), Dr. Carlos Augusto Rodrigues Matrangolo (Universidade Estadual de Montes Claros, Minas Gerais, Brazil - Formicidae), Dr. Ivan Cardoso Nascimento (Universidade Estadual do Sudoeste da Bahia, Bahia, Brasil - Formicidae), Dra. Luci Boa Nova Coelho (Universidade Federal do Rio de Janeiro, Brasil - Cicadellidae), and Dr. Paulo Sérgio Fiuza Ferreira (Universidade Federal de Viçosa, Minas Gerais, Brasil Hemiptera) for arthropod species identifications. The study was financially supported by the following Brazilian agencies "Conselho Nacional de Desenvolvimento Científico e Tecnológico (CNPq)", "Fundação de Amparo à Pesquisa do Estado de Minas Gerais (FAPEMIG)", and "Programa Cooperativo sobre Proteção Florestal (PROTEF) do Instituto de Pesquisas e Estudos Florestais (IPEF)".

\section{References}

AGUIAR JUNIOR, A., BARBOSA, R.I., BARBOSA, J.B.F. and MOURÃO JUNIOR, J.R., 2014. Invasion of Acacia mangium in Amazonian savannas following planting for forestry. Plant Ecology $\mathcal{E}$ Diversity, vol. 7, no. 1-2, pp. 359-369. http://dx.doi.org/10.108 0/17550874.2013.771714.

ALVARES, C.A., STAPE, J.L., SENTELHAS, P.C. and GONÇALVES, J.L.M., 2013. Modelling monthly mean air temperature for Brazil. Theoretical and Applied Climatology, vol. 113, no. 3-4, pp. 407427. http://dx.doi.org/10.1007/s00704-012-0796-6.

BALIEIRO, F.C., COSTA, C.A., OLIVEIRA, R.B., DONAGEMMA, G.K., ANDRADE, A.G. and CAPECHE, C.L., 2017. Carbon stocks in mined area reclaimed by leguminous trees and sludge. Revista Árvore, vol. 41, no. 6, pp. e410610.

BEGON, M., TOWNSEND, C.R. and HARPER, J.L., 2007. Ecologia: de indivíduos a ecossistemas. 4th ed. Porto Alegre: Artmed.

DAMASCENA, J.G., LEITE, G.L.D., SILVA, F.W.S., SOARES, M.A., GUANABENS, R.E.M., SAMPAIO, R.A. and ZANUNCIO, J.C., 2017. Spatial distribution of phytophagous insects, natural enemies, and pollinators on Leucaena leucocephala (Fabaceae) trees in the Cerrado. Florida Entomologist, vol. 100, no. 3, pp. 558-565.

DIOUF, D., DUPONNOIS, R., BA, A.T., NEYRA, M. and LESUEUR, D., 2006. Symbiosis of Acacia auriculiformis and Acacia mangium with mycorrhizal fungi and Bradyrhizobium spp. improves salt tolerance in greenhouse conditions. Functional Plant Biology, vol. 32, no. 12, pp. 1143-1152. http://dx.doi.org/10.1071/FP04069. PMid:32689208.

DORAN, J.C. and TURNBULL, J.W., 1997. Australian trees and shrubs: species for land rehabilitation and farm planting in the tropics. Canberra: ACIAR.
FELICIO, T.N.P., COSTA, T.L., SARMENTO, R.A., RAMOS, R.S., PEREIRA, P.S., SILVA, R.S. and PICANÇO, M.C., 2019. Surrounding vegetation, climatic elements, and predators affect the spatial dynamics of Bemisia tabaci (Hemiptera: Aleyrodidae) in commercial melon fields. Journal of Economic Entomology, vol. 112, no. 6, pp. 27742781. http://dx.doi.org/10.1093/jee/toz181. PMid:31265728.

FIENE, J., KALNS, L., NANSEN, C., BERNAL, J., HARRIS, M. and SWORD, G.A., 2013. Foraging on individual leaves by an intracellular feeding insect is not associated with leaf biomechanical properties or leaf orientation. PLoS One, vol. 8, no. 11, pp. e80911. http://dx.doi.org/10.1371/journal.pone.0080911. PMid:24260510.

FIRMANSYAH, M.A., ERFIANI, E., JAYANEGARA, A., ACHMAD, A. and WIJAYANTO, N., 2020. In vitro biological control of Ceratobasidium ramicola by using tannin extracts from Acacia villosa, Myristica fragrans, Acacia mangium, and Calliandra calothyrsus leaves. Brazilian Journal of Biology $=$ Revista Brasileira de Biologia, vol. 80, no. 2, pp. 235-239. http://dx.doi. org/10.1590/1519-6984.184912. PMid:31482970.

GEE, J.M., WARWICK, R.M., SCHAANNING, M., BERGE, J.A. and AMBROSE JUNIOR, W.G., 1985. Effects of organic enrichment on meiofaunal abundance and community structure in sublittoral soft sediments. Journal of Experimental Marine Biology and Ecology, vol. 91, no. 3, pp. 247-262. http://dx.doi. org/10.1016/0022-0981(85)90179-0.

GHOSH, D., 2015. Morphology, anatomy, ultrastructure and antpatrolling of extrafloral nectaries (EFNS) in tree species of Mimosaceae. International Journal of Current Research, vol. 7, no. 5, pp. 15505-15508.

GIANNINI, T.C., ACOSTA, A.L., GARÓFALO, C.A., SARAIVA, A.M., ALVES-DOS-SANTOS, I. and IMPERATRIZ-FONSECA, V.L., 2012. Pollination services at risk: bee habitats will decrease owing to climate change in Brazil. Ecological Modelling, vol. 244, no. 10, pp. 127-131. http://dx.doi.org/10.1016/j.ecolmodel.2012.06.035.

GORB, E. and GORB, S., 2009. Effects of surface topography and chemistry of Rumex obtusifolius leaves on the attachment of the beetle Gastrophysa viridula. Entomologia Experimentalis et Applicata, vol. 130, no. 3, pp. 222-228. http://dx.doi. org/10.1111/j.1570-7458.2008.00806.x.

GORB, E., VOIGT, D., EIGENBRODE, S.D. and GORB, S., 2008. Attachment force of the beetle Cryptolaemus montrouzieri (Coleoptera, Coccinellidae) on leaflet surfaces of mutants of the pea Pisum sativum (Fabaceae) with regular and reduced wax coverage. Arthropod-Plant Interactions, vol. 2, no. 4, pp. 247-259. http://dx.doi.org/10.1007/s11829-008-9049-0.

GRÜTER, C., KÄRCHER, M. and RATNIEKS, F.L., 2011. The natural history of nest defence in a stingless bee, Tetragonisca angustula (Latreille) (Hymenoptera: Apidae), with two distinct types of entrance guards. Neotropical Entomology, vol. 40, no. 1, pp. 55-61. http://dx.doi.org/10.1590/S1519-566X2011000100008. PMid:21437483.

HAGER, F.A. and KRAUSA, K., 2019. Acacia ants respond to plantborne vibrations caused by mammalian browsers. Current Biology, vol. 29, no. 5, pp.717-725.

HEGDE, M., PALANISAMY, K. and YI, J.S., 2013. Acacia mangium Willd. - a fast growing tree for tropical plantation. Journal of Forest Science, vol. 29, no. 1, pp. 1-14. http://dx.doi.org/10.7747/ JFS.2013.29.1.1.

HILL, M.O., 1973. Diversity and evenness: a unifying notation and its consequences. Ecology, vol. 54, no. 2, pp. 427-432. http:// dx.doi.org/10.2307/1934352.

KIM, S., JUNG, M., SONG, Y.J., KANG, C., KIM, B.Y., CHOI, I.J., KIM, H.G. and LEE, D.H., 2017. Evaluating the potential of the extract of Perilla sp. as a natural insecticide for Bemisia tabaci (Hemiptera: Aleyrodidae) on sweet peppers. Entomological Research, vol. 47, no. 3, pp. 208-216. http://dx.doi.org/10.1111/1748-5967.12211. 
KREBS, C.J., 1989. Bray-Curtis cluster analysis. 1. Biodiversity Pro Version 2.0 [online]. Available from: http://biodiversity-pro. software.informer.com/

LAMBSHEAD, P.J.D., PLATT, H.M. and SHAW, K.M., 1983. The detection of differences among assemblages of marine benthic species based on an assessment of dominance and diversity. Journal of Natural History, vol. 17, no. 6, pp. 859-874.

LE GOFF, G.L., MAILLEUX, A.C., DETRAIN, C., DENEUBOURG, J.L., CLOTUCHE, G. and HANCE, T., 2009. Spatial distribution and inbreeding in Tetranychus urticae. Comptes Rendus Biologies, vol. 332, no. 10, pp. 927-933. http://dx.doi.org/10.1016/j. crvi.2009.06.002. PMid:19819413.

LEITE, G.L.D., PICANÇO, M., ZANUNCIO, J.C., MOREIRA, M.D. and JHAM, G.N., 2011. Hosting capacity of horticultural plants for insect pests in Brazil. Chilean Journal of Agricultural Research, vol. 71, no. 3, pp. 383-389.

LEITE, G.L.D., PIMENTA, M., FERNANDES, P.L., VELOSO, R.V.S. and MARTINS, E.R., 2008. Fatores que afetam artrópodes associados a cinco acessos de ginseng-brasileiro (Pfaffia glomerata) em Montes Claros, Estado de Minas Gerais. Acta Scientiarum Agronomy, vol. 30, no. 1, pp. 7-11. http://dx.doi.org/10.4025/ actasciagron.v30i1.1110.

LIMA, T.E., SARTORI, A.L.B. and RODRIGUES, M.L.M., 2017. Plant antiherbivore defenses in Fabaceae species of the Chaco. Brazilian Journal of Biology = Revista Brasileira de Biologia, vol. 77, no. 2, pp. 299-303. http://dx.doi.org/10.1590/1519-6984.12815. PMid:27599100.

LONDE, V., SOUSA, H.C. and MESSIAS, M.C.T.B., 2020. Monitoring of forest components reveals that exotic tree species are not always invasive in areas under ecological restoration. Environmental Monitoring and Assessment, vol. 192, no. 10, pp. 618-628. http:// dx.doi.org/10.1007/s10661-020-08583-w. PMid:32880735.

MANSARAY, A. and SUNDUFU, A.J., 2009. Oviposition, development and survivorship of the sweetpotato whitefly Bemisia tabaci on soybean, Glycine max, and the garden bean, Phaseolus vulgaris. Journal of Insect Science, vol. 9, no. 1, pp. 1-6. http://dx.doi. org/10.1673/031.009.0101. PMid:19611218.

MAOELA, M.A., ROETS, F., JACOBS, S.M. and ESLER, K.J., 2016. Restoration of invaded Cape Floristic Region riparian systems leads to a recovery in foliage-active arthropod alpha- and beta-diversity. Journal of Insect Conservation, vol. 20, pp. 85-97.

NARANJO, S. and FLINT, H.M., 1995. Spatial distribution of adult of adult Bemisia tabaci (Homoptera: Aleyrodidae) in cotton and development of fixed precision sequential sampling plans for estimating population density. Environmental Entomology, vol. 24, no. 2, pp. 261-270. http://dx.doi.org/10.1093/ee/24.2.261.

NOVGORODOVA, T.A., 2015. Organization of honeydew collection by foragers of different species of ants (Hymenoptera: formicidae) European Journal of Entomology, vol. 112, no. 4, pp. 688-697. http://dx.doi.org/10.14411/eje.2015.077.

OLIVEIRA, J.O., PASCHOAL, L.R.P. and NUNES, J.F., 2021. Danger next door: new record of the whitefly Bemisia tabaci near to the Serra da Canastra National Park (southeast Brazil). Brazilian Journal of Biology = Revista Brasileira de Biologia, vol. 81, no. 4, pp. 1115-1117. http://dx.doi.org/10.1590/1519-6984.228707. PMid:33053120.

PEETERS, P.J., 2002. Correlations between leaf structural traits and the densities of herbivorous insect guilds. Biological Journal of the Linnean Society, vol. 77, no. 1, pp. 43-65. http://dx.doi. org/10.1046/j.1095-8312.2002.00091.x.

PRÜM, B., SEIDEL, R., BOHN, H.F. and SPECK, T., 2012. Plant surfaces with cuticular folds are slippery for beetles. Journal of the Royal Society Interface, vol. 9, no. 66, pp. 127-135.

RAHMAN, M., RAHMAN, A., MIAH, G., SAHA, S.R., KARIM, M.A. and MOSTOFA, M.G., 2017. Mechanistic insight into salt tolerance of Acacia auriculiformis: the importance of ion selectivity, osmoprotection, tissue tolerance, and $\mathrm{Na}^{+}$exclusion. Frontiers in Plant Science, vol. 8, pp. 155. http://dx.doi.org/10.3389/ fpls.2017.00155. PMid:28421081.

RANA, V. and MAITI, S.K., 2018. Differential distribution of metals in tree tissues growing on reclaimed coal mine overburden dumps, Jharia coal field (India). Environmental Science and Pollution Research International, vol. 25, no. 10, pp. 9745-9758. http://dx.doi.org/10.1007/s11356-018-1254-5. PMid:29368202.

RICE, E.L. and KELTING, R.W., 1955. The species-area curve. Ecology, vol. 36, no. 1, pp. 7-11. http://dx.doi.org/10.2307/1931423.

RODRÍGUEZ, J., CORDERO-RIVERA, A. and GONZÁLEZ, L., 2020. Characterizing arthropod communities and trophic diversity in areas invaded by Australian acacias. Arthropod-Plant Interactions, vol. 14, no. 4, pp. 531-545. http://dx.doi.org/10.1007/s11829020-09758-5.

SAGATA, K. and GIBB, H., 2016. The effect of temperature increases on an ant-Hemiptera-plant interaction. PLOS ONE, vol. 11, no. 7, pp. e0155131.

SALERNO, G., REBORA, M., GORB, E. and GORB, S., 2018. Attachment ability of the polyphagous bug Nezara viridula (Heteroptera: Pentatomidae) to different host plant surfaces. Scientific Reports, vol. 8, no. 1, pp. 10975. http://dx.doi.org/10.1038/s41598-01829175-2. PMid:30030448.

SANCHEZ, J.A., LÓPEZ-GALLEGO, E. and LA-SPINA, M., 2020. The impact of ant mutualistic and antagonistic interactions on the population dynamics of sap-sucking hemipterans in pear orchards. Pest Management Science, vol. 76, no. 4, pp. 1422-1434. http://dx.doi.org/10.1002/ps.5655. PMid:31628776.

SILVA, J.L., LEITE, G.L.D., TAVARES, W.S., SILVA, F.W.S., SAMPAIO, R.A., AZEVEDO, A.M., SERRÃO, J.E. and ZANUNCIO, J.C., 2020. Diversity of arthropods on Acacia mangium (Fabaceae) and production of this plant with dehydrated sewage sludge in degraded area. Royal Society Open Science, vol. 7, no. 2, pp. 191196. http://dx.doi.org/10.1098/rsos.191196. PMid:32257306.

SISTEMA PARA ANÁLISES ESTATÍSTICAS - SAEG, 2007. Version 9.1 [software]. Viçosa: Fundação Arthur Bernardes, UFV. Available from: http://arquivo.ufv.br/saeg

VAN DER COLFF, D., DREYER, L.L., VALENTINE, A. and ROETS, F., 2015. Invasive plant species may serve as a biological corridor for the invertebrate fauna of naturally isolated hosts. Journal of Insect Conservation, vol. 19, no. 5, pp. 863-875. http://dx.doi. org/10.1007/s10841-015-9804-3.

WICKNESWARI, R. and NORWATI, M., 1993. Genetic diversity of natural-populations of Acacia auriculiformis. Australian Journal of Botany, vol. 41, pp. 65-77.

WILCOXON, F., 1945. Individual comparisons by ranking methods. Biometrics Bulletin, vol. 1, no. 6, pp. 80-83. http://dx.doi. org/10.2307/3001968.

WONG, M.M., CANNON, C.H. and WICKNESWARI, R., 2011. Identification of lignin genes and regulatory sequences involved in secondary cell wall formation in Acacia auriculiformis and Acacia mangium via de novo transcriptome sequencing. BMC Genomics, vol. 12, pp. 342. http://dx.doi.org/10.1186/1471-216412-342. PMid:21729267.

ZHANG, W., MCAUSLANE, H.J. and SCHUSTER, D.J., 2004. Repellency of ginger oil to Bemisia argentifolii (Homoptera: Aleyrodidae) on tomato. Journal of Economic Entomology, vol. 97, no. 4, pp. 13101318. http://dx.doi.org/10.1093/jee/97.4.1310. PMid:15384342. 
Silva, L.F. et al.

\section{Supplementary Material}

Supplementary material accompanies this paper.

Supplementary material I. Number of arthropods per leaf (mean \pm SE) on Acacia auriculiformis (Fabaceae) saplings

This material is available as part of the online article from http://www.scielo.br/bjb 